\title{
Environmental Awareness of Teacher Candidates
}

\author{
Demirali Yaşar Ergin ${ }^{1, *}$ \\ ${ }^{1}$ Faculty of Education, Trakya University, Edirne, Turkey \\ *Correspondence: Trakya Universitesi Kosova Yerleşkesi, Eğitim Fakültesi, Edirne, Turkey. Tel: 90-505-925-5377. \\ E-mail: demiraliergin@gmail.com
}

This article was presented as abstract at the "3rd International Conference on Lifelong Education and Leadership for All. ICLEL 2017/September 12-14/Polytechnic Instute of Porto, Porto-Portogual"

Received: December 24, $2018 \quad$ Accepted: January 26, 2019 Online Published: February 15, 2019

doi:10.5430/wje.v9n1p152 URL: https://doi.org/10.5430/wje.v9n1p152

\begin{abstract}
The aim of this research was to determine the environmental awareness of teacher candidates. According to this aim the research was carried out with a total of 532 students randomly selected from all departments of Trakya University Faculty of Education and Pedagogical Formation program students during the fall semester of 2016-2017. "Environmental Awareness Scale" prepared by the researcher was used as data collection tool. The scale consists of 71 items with a rating of 4 . For each sub-scale, the internal consistency was determined by calculating the item-total correlation coefficient and item-remainder correlation coefficient. In the same way, t-test between the upper quartile and the lower quartile was applied to detect the discrimination power of the items. For the scale and sub-scales, the reliability was determined by calculating the Cronbach and Rulon coefficients. It was determined that the scale consisting of 3 factors was valid, reliable and usable after statistical procedures. High scores in all items and factors indicate positive environmental awareness.

A questionnaire consisting of 19 questions prepared by the researcher was used to collect data about the independent variables of the research. The questionnaire contains questions about nature love as well as demographic characteristics such as gender and age. The statistical analysis of data featured $t$ test, variance analysis and LSD methods for Post hoc analysis to determine the source of variation. In this research, generally it was found that the environmental awareness of the candidate teachers was very high.
\end{abstract}

Keywords: environment, environmentalism, environmental awareness

\section{Introduction}

Natural assets are the conditions of our existence, having existed till today, allowing today and the future to be lived. The future will be preserved as long as they are protected. Also defined as the environment, these natural assets can also be defined as the habitat to which all living things maintain a relationship throughout their lifetime. The world is struggling to cope with environmental issues that have long existed, but become increasingly effective on one hand, and the emerging environmental issues on the other. Deforestation, loss of biodiversity, air pollution, nutritional issues, global climate change and similar issues that are directly or indirectly related to the environment are growing exponentially. While global climate change is the leading threat to the planet and life today, it is now evident that we are in the foresteps of irreversible destruction. Civilization is at the threshold of permanent crises which may significantly affect the life on the planet at a point where all living things, including mankind, are threatened. The leading causes of environmental crises, the energy industry is strategic, but also prominent in environmental discussions due to its role in global climate change.

Today, environmental problems are gathered at four main points. 1) The destruction of the ecological balance, destruction of the natural order to completely disrupt the balances, 2) The waste of natural resources, 3) Not struggling to eliminate natural disaster, 4) The insufficient use of renewable energy sources. Scientists have serious discoveries and worries that the world cannot solve environmental problems, especially global warming, and that the world will become a planet of disasters within this century. The only way to solve the problems that humans have is 
the most intelligent being on the planet is science. Informing and raising awareness happens through education. If we want to leave a livable world to future generations, we must educate everybody in this matter, especially children. It is in this point that the teachers who realize these trainings have environmental awareness.

Solving environmental issues is only possible by raising awareness on such issues and the environment. This is a process of education. It will be possible to succeed if the educational process through formal and informal channels is maintained. Environmental education to raise awareness on environment can be provided informally by the family, by mass communication, internet, social networks and similar methods of influence. But in addition to all of the above, the important thing is to provide formal education on environment. Educational activities with contents to raise the environmental awareness of students of all age should be carried out.

Environmental education is a new field of education that emerged when we realized that the distortion of environment, resulting from mankind's efforts to dominate the nature, can only be remedied by mankind's efforts again (Özdemir, 2016). By realizing that the distortion of the environment caused by mankind's interaction with the nature can be remedied again by mankind, environmental education is considered the primary method of creating the required change in people's cognitive, sensory and behavioral aspects (Özdemir, 2007).

The foundation of environmental education is intended to protect the nature and natural resources. In addition to informing, environmental education also affects human behavior. Providing positive and permanent changes in behavior and ensuring active participation of individuals in solving problems are the fundamental objectives of environmental education (Şimşekli, 2004).

It is necessary that the candidate teachers, who will be providing environmental education in schools, should themselves gain awareness of the environment in Educational Faculties, then receive education on the methods to provide environmental education depending on their expertise and level. The initial point for raising awareness is teachers at all levels.

\section{Method}

The study was carried out with a total of 532 students randomly selected from all departments of Trakya University Faculty of Education and Pedagogical Formation program students during the fall semester of 2016-2017. "Environmental Awareness Scale" prepared by the researcher was used as data collection tool.

"Environmental Awareness Scale" consists of 71 items with a rating of 4. For each sub-scale, the internal consistency was determined by calculating the item-total correlation coefficient and the internal consistency was calculated by calculating the total correlation coefficient excluding item. In the same way, t-test between the upper quartile and the lower quartile was applied to detect the discrimination power of the items. For the scale and sub-scales, the reliability was determined by calculating the Cronbach and Rulon coefficients. It was determined that the scale consisting of 3 factors was valid, reliable and usable after statistical procedures. High scores in all items and factors indicate positive environmental awareness (Ergin, 2017).

A questionnaire consisting of 19 questions prepared by the researcher was used to collect data about the independent variables of the research. The questionnaire contains questions about nature love as well as demographic characteristics such as gender and age.The statistical analysis of data featured $t$ test, variance analysis and LSD methods for Post hoc analysis to determine the source of variation.

\section{Results}

In this part of the study, the results obtained from the study are presented.

Table 1. Descriptive Statistics

\begin{tabular}{lccccccc}
\hline & $\mathrm{n}$ & Mean & Std. deviation & \multicolumn{2}{c}{ Skewness } & \multicolumn{2}{c}{ Kurtosis } \\
\cline { 2 - 8 } & Statistic & Statistic & Statistic & Statistic & Std. error & Statistic & Std. error \\
\hline To do & 532 & 3.647 & 0.301 & -2.774 & 0.106 & 14.133 & 0.211 \\
Not to do & 532 & 3.620 & 0.348 & -2.487 & 0.106 & 10.390 & 0.211 \\
Current Threats & 532 & 3.661 & 0.485 & -2.825 & 0.106 & 9.649 & 0.211 \\
Total environmental awareness & 532 & 3.642 & 0.295 & -1.886 & 0.106 & 4.734 & 0.211 \\
\hline
\end{tabular}


It is evident, based on the totals and the sub-scales, that the candidate teachers have a very high level of environmental awareness, by 3,6/4 (max). In addition, the results of the skewness and kurtosis analyses demonstrated that the distribution is normal, thus the parametric statistics are eligible (Table 1).

Table 2. Environmental Awareness T Test Results by Gender

\begin{tabular}{llcccccc}
\hline & & $\mathrm{n}$ & Mean & Std. deviation & $\mathrm{t}$ & $\mathrm{df}$ & Sig. (2-tailed) \\
\hline \multirow{2}{*}{ To do } & Female & 427 & 3.666 & 0.275 & 2.972 & 530 & 0.003 \\
\multirow{2}{*}{ Not to do } & Male & 105 & 3.569 & 0.380 & & & \\
\multirow{2}{*}{ Current threats } & Female & 427 & 3.640 & 0.310 & 2.683 & 530 & 0.008 \\
\multirow{2}{*}{ Total environmental awareness } & Male & 105 & 3.539 & 0.467 & & & \\
& Female & 427 & 3.693 & 0.455 & 3.138 & 530 & 0.002 \\
& Male & 105 & 3.529 & 0.574 & & & \multirow{2}{*}{0.000} \\
& Female & 427 & 3.666 & 0.267 & 3.800 & 530 & 0.000 \\
& Male & 105 & 3.546 & 0.377 & & & \\
\hline
\end{tabular}

The candidate teachers' environmental awareness varied by gender in the three sub-scales and the total awareness. Female candidate teachers have more positive environmental awareness in the three sub-scales and the total score compared to men. (Table 2).

Table 3. Environmental Awareness T Test Results by Marital Status

\begin{tabular}{llcccccc}
\hline & & $\mathrm{n}$ & Mean & Std. deviation & $\mathrm{t}$ & df & Sig. (2-tailed) \\
\hline \multirow{2}{*}{ To do } & Single & 495 & 3.638 & 0.305 & -2.391 & 530 & 0.017 \\
\multirow{2}{*}{ Not to do } & Married & 37 & 3.760 & 0.205 & & & \\
\multirow{2}{*}{ Current threats } & Single & 495 & 3.621 & 0.332 & 0.219 & 530 & 0.827 \\
\multirow{2}{*}{ Total environmental awareness } & Married & 37 & 3.608 & 0.526 & & & \\
& Single & 495 & 3.648 & 0.487 & -2.190 & 530 & 0.029 \\
& Married & 37 & 3.828 & 0.419 & & & \multirow{2}{*}{0.055} \\
& Single & 495 & 3.636 & 0.296 & -1.921 & 530 & 0.03 \\
& Married & 37 & 3.732 & 0.272 & & & \\
\hline
\end{tabular}

Candidate teachers' environmental awareness in To do $(\mathrm{t}=-2,392 \mathrm{df}=530 \mathrm{p}<.05)$ and Current Threats $(\mathrm{t}=-2,190$ $\mathrm{df}=530 \mathrm{p}<.05)$ sub scales varied by marital status. Married candidate teachers have more positive environmental awareness in these two sub-scales compared to single ones (Table 3).

Table 4. Environmental Awareness T Test Results by Like of Flowers, Trees, Greenery

\begin{tabular}{lccccccc}
\hline & & $\mathrm{n}$ & Mean & Std. deviation & $\mathrm{t}$ & $\mathrm{df}$ & Sig. (2-tailed) \\
\hline \multirow{2}{*}{ To do } & Yes & 523 & 3.651 & 0.296 & 2.530 & 530 & 0.012 \\
\multirow{3}{*}{ Not to do } & No & 9 & 3.397 & 0.454 & & & \\
\multirow{2}{*}{ Current threats } & Yes & 523 & 3.624 & 0.348 & 1.782 & 530 & 0.075 \\
\multirow{2}{*}{ Total environmental awareness } & No & 9 & 3.416 & 0.325 & & & \\
& Yes & 523 & 3.667 & 0.479 & 2.396 & 530 & 0.017 \\
& No & 9 & 3.278 & 0.676 & & & \\
& Yes & 523 & 3.647 & 0.290 & 2.878 & 530 & 0.004 \\
& No & 9 & 3.364 & 0.448 & & & \\
\hline
\end{tabular}

Candidate teachers' environmental awareness in To do $(\mathrm{t}=2,530 \mathrm{df}=530 \mathrm{p}<.05)$ and Current Threats $(\mathrm{t}=2,396 \mathrm{df}=530$ $\mathrm{p}<.05)$ sub scales and the total awareness $(\mathrm{t}=2,878 \mathrm{df}=530 \mathrm{p}<.01)$ varied by their favoring of flowers, trees and greens. Candidate teachers who indicate they like flowers, trees and greens have more positive environmental awareness in these two sub scales and the total score compared to candidate teachers who do not like such. (Table 4). 
Table 5. Environmental Awareness T Test Results by Respectful of the Rights of Living Beings Outside of Humans

\begin{tabular}{lccccccc}
\hline & & $\mathrm{n}$ & Mean & Std. deviation & $\mathrm{t}$ & $\mathrm{df}$ & Sig. (2-tailed) \\
\hline \multirow{2}{*}{ To do } & Yes & 523 & 3.653 & 0.283 & 3.597 & 530 & 0.000 \\
& No & 9 & 3.294 & 0.796 & & & \\
\multirow{2}{*}{ Not to do } & Yes & 523 & 3.621 & 0.349 & 0.203 & 530 & 0.839 \\
& No & 9 & 3.597 & 0.269 & & & \\
Current threats & Yes & 523 & 3.667 & 0.478 & 2.135 & 530 & 0.033 \\
\multirow{5}{*}{ Total environmental awareness } & No & 9 & 3.320 & 0.763 & & & \\
& Yes & 523 & 3.647 & 0.289 & 2.462 & 530 & 0.014 \\
& No & 9 & 3.403 & 0.533 & & & \\
\hline
\end{tabular}

Candidate teachers' environmental awareness in To do $(\mathrm{t}=3,597 \mathrm{df}=530 \mathrm{p}<.01)$ and Current Threats $(\mathrm{t}=2,135 \mathrm{df}=530$ $\mathrm{p}<.05)$ sub scales and the total score $(\mathrm{t}=2,462 \mathrm{df}=530 \mathrm{p}<.05)$ varied depending on whether they respect the rights of non-human living beings. Candidate teachers who indicate that they are respectful of the rights of non-human living beings have more positive environmental awareness in these two sub scales and the total score compared to candidate teachers who are not respectful of the rights of non-human living beings (Table 5).

Table 6. Environmental Awareness t Test Results by Knowing about the Negative Effects of Damage to Nature and Animals in the Future

\begin{tabular}{lccccccc}
\hline & & $\mathrm{n}$ & Mean & Std. deviation & $\mathrm{t}$ & $\mathrm{df}$ & Sig. (2-tailed) \\
\hline \multirow{2}{*}{ To do } & Yes & 472 & 3.659 & 0.299 & 2.649 & 530 & 0.008 \\
\multirow{3}{*}{ Not to do } & No & 60 & 3.551 & 0.298 & & & \\
\multirow{2}{*}{ Current threats } & Yes & 472 & 3.624 & 0.344 & 0.709 & 530 & 0.479 \\
\multirow{5}{*}{ Total environmental awareness } & No & 60 & 3.590 & 0.379 & & & \\
& Yes & 472 & 3.664 & 0.494 & 0.438 & 530 & 0.662 \\
& No & 60 & 3.635 & 0.403 & & & \\
& Yes & 472 & 3.649 & 0.297 & 1.413 & 530 & 0.158 \\
& No & 60 & 3.592 & 0.281 & & & \\
\hline
\end{tabular}

Candidate teachers' environmental awareness in To do $(\mathrm{t}=2,649 \mathrm{df}=530 \mathrm{p}<.01)$ sub scales vary by whether they are informed about the future negative effects of damage to nature and animals. Candidate teachers who indicate they are informed about the future negative effects of damage to nature and animals have more positive environmental awareness in this sub scale compared to candidate teachers who indicated they are not informed (Table 6).

Table 7. Environmental Awareness t Test Results by Accepting Nature and Animals as Part of Your Life / Family

\begin{tabular}{lccccccc}
\hline & & $\mathrm{n}$ & Mean & Std. deviation & $\mathrm{t}$ & $\mathrm{df}$ & Sig. (2-tailed) \\
\hline \multirow{2}{*}{ To do } & Yes & 467 & 3.657 & 0.293 & 2.157 & 530 & 0.031 \\
\multirow{2}{*}{ Not to do } & No & 65 & 3.572 & 0.344 & & & \\
\multirow{2}{*}{ Current Threats } & Yes & 467 & 3.627 & 0.353 & 1.145 & 530 & 0.253 \\
\multirow{2}{*}{ Total Environmental Awareness } & No & 65 & 3.574 & 0.310 & & & \\
& Yes & 467 & 3.666 & 0.489 & 0.732 & 530 & 0.465 \\
& No & 65 & 3.619 & 0.456 & & & \multirow{2}{*}{0.114} \\
& Yes & 467 & 3.650 & 0.293 & 1.583 & 530 & \multirow{2}{*}{0.114} \\
& No & 65 & 3.588 & 0.311 & & & \\
\hline
\end{tabular}

Candidate teachers' environmental awareness in To do $(\mathrm{t}=2,157 \mathrm{df}=530 \mathrm{p}<.05)$ sub scales vary by accepting nature and animals as part of their life/family. Candidate teachers who indicate they see nature and animals as part of their life/family have more positive environmental awareness compared to candidate teachers who indicate otherwise (Table 7).

The results of the Test of Homogeneity of Variances have shown that the scale totals and the subscales are homogeneous and ANOVA is usable (Table 8). 
Table 8. Test of Homogeneity of Variances

\begin{tabular}{lcccc}
\hline & Levene statistic & df1 & df2 & Sig. \\
\hline To do & 2.269 & 2 & 529 &, 104 \\
Not to do &, 310 & 2 & 529 &, 734 \\
Current threats & 2.336 & 2 & 529 &, 098 \\
Total environmental awareness & 2.338 & 2 & 529 &, 098 \\
\hline
\end{tabular}

Candidate teachers' environmental awareness in Total $(\mathrm{F}=3,035 \mathrm{df}=2-529 \mathrm{p}<.05)$ and To do $(\mathrm{F}=3,860 \mathrm{df}=2-529$ $\mathrm{p}<.05$ ) sub scales show variation by their age (Table 9 ).

Table 9. ANOVA Results by Age

\begin{tabular}{llccccc}
\hline & & Sum of squares & df & Mean square & F & Sig. \\
\hline \multirow{4}{*}{ To do } & Between groups & 0.690 & 2 & 0.345 & 3.860 & 0.022 \\
& Within groups & 47.270 & 529 & 0.089 & & \\
& Total & 47.960 & 531 & & & \\
\multirow{5}{*}{ Total environmental awareness } & Between groups & 0.525 & 2 & 0.263 & 3.035 & 0.049 \\
& Within groups & 45.773 & 529 & 0.087 & & \\
& Total & 46.298 & 531 & & & \\
\hline
\end{tabular}

Descriptive statistics on the environmental awareness of candidate teachers varied by their age are as follows (Table 10).

Table 10. ANOVA Descriptive Statistics by Age

\begin{tabular}{llccc}
\hline & & $\mathrm{n}$ & Mean & Std. deviation \\
\hline \multirow{4}{*}{ To do } & $18-25$ & 473 & 3.634 & 0.309 \\
& $26-35$ & 49 & 3.751 & 0.203 \\
& 36 and over & 10 & 3.736 & 0.162 \\
& Total & 532 & 3.647 & 0.301 \\
Total environmental awareness & $18-25$ & 473 & 3.631 & 0.301 \\
& $26-35$ & 49 & 3.728 & 0.243 \\
& 36 and over & 10 & 3.748 & 0.147 \\
& Total & 532 & 3.642 & 0.295 \\
\hline
\end{tabular}

According to the results of the LSD Post Hoc related to the candidate teachers' variable environmental awareness in Total and To do sub scales, candidate teachers aged 18-25 display a more negative environmental awareness compared to candidate teachers aged 26-35 (Table 11).

Table 11. ANOVA LSD Post Hoc Results by Age

\begin{tabular}{lllccc}
\hline Dependent variable & & & Mean difference (I-J) & Std. error & Sig. \\
\hline \multirow{2}{*}{ To do } & \multirow{2}{*}{$18-25$} & $26-35$ & -0.117 & 0.045 & 0.009 \\
& & 36 and over & -0.102 & 0.096 & 0.288 \\
\multirow{2}{*}{ Total environmental awareness } & \multirow{2}{*}{$18-25$} & $26-35$ & -0.096 & 0.044 & 0.029 \\
& & 36 and over & -0.116 & 0.094 & 0.217 \\
\hline
\end{tabular}

Candidate teachers' environmental awareness in Current Threats $(\mathrm{F}=3,108 \mathrm{df}=3-528 \mathrm{p}<.05)$ sub scale vary by which class they study in (Table 12).

Table 12. ANOVA Results by Class

\begin{tabular}{llccccc}
\hline & & Sum of squares & df & Mean square & F & Sig. \\
\hline \multirow{4}{*}{ Current threats } & Between groups & 2.166 & 3 & 0.722 & 3.108 & 0.026 \\
& Within groups & 122.640 & 528 & 0.232 & & \\
& Total & 124.805 & 531 & & & \\
\hline
\end{tabular}


Descriptive statistics on the environmental awareness of candidate teachers varied by which class they study in are as follows (Table 13).

Table 13. ANOVA Descriptive Statistics by Class

\begin{tabular}{llccc}
\hline & & $\mathrm{n}$ & Mean & Std. deviation \\
\hline \multirow{5}{*}{ Current threats } & 1. year & 85 & 3.795 & 0.230 \\
& 2.year-3.year & 288 & 3.622 & 0.491 \\
& 4. year & 67 & 3.700 & 0.404 \\
& Formation & 92 & 3.629 & 0.648 \\
& Total & 532 & 3.661 & 0.485 \\
\hline
\end{tabular}

According to the results of the LSD Post Hoc related to the candidate teachers' variable environmental awareness in Current Threats sub scale candidate teachers studying the 1. Year have a more positive environmental awareness level compared to candidate teahcers in the 2.year-3.year and formation classes (Table 14).

Table 14. ANOVA LSD Post Hoc Results by Class

\begin{tabular}{|c|c|c|c|c|c|}
\hline \multicolumn{3}{|c|}{ Dependent variable } & Mean difference (I-J) & Std. error & Sig. \\
\hline \multirow{3}{*}{ Current threats } & \multirow{3}{*}{ 1. year } & 2.year-3.year & 0.173 & 0.059 & 0.004 \\
\hline & & 4. year & 0.095 & 0.079 & 0.226 \\
\hline & & Formation & 0.166 & 0.073 & 0.023 \\
\hline
\end{tabular}

Candidate teachers' Total Environmental Awareness $(\mathrm{F}=3,182 \mathrm{df}=4-396 \mathrm{p}<.05)$ vary by the most important reason in choosing where to live (Table 15).

Table 15. ANOVA Results by Choosing a Living Place

\begin{tabular}{llccccc}
\hline & & Sum of squares & df & Mean square & F & Sig. \\
\hline \multirow{4}{*}{ Total environmental awareness } & Between groups & 1.079 & 4 & 0.270 & 3.182 & 0.014 \\
& Within groups & 33.569 & 396 & 0.085 & & \\
& Total & 34.648 & 400 & & & \\
\hline
\end{tabular}

Descriptive statistics on the environmental awareness of candidate teachers varied by the most important reason in choosing where they live are as follows (Table 16).

Table 16. ANOVA Descriptive Statistics by Choosing a Living Place

\begin{tabular}{llccc}
\hline & $\mathrm{n}$ & Mean & Std. deviation \\
\hline & Degradation of natural beauties & 24 & 3.484 & 0.420 \\
& Concrete & 68 & 3.714 & 0.283 \\
& Air/water pollution concern & 18 & 3.707 & 0.212 \\
\cline { 2 - 4 } Total environmental awareness & Relinquishment also demands to leave & 8 & 3.719 & 0.173 \\
& Other & 283 & 3.636 & 0.287 \\
& Total & 401 & 3.645 & 0.294 \\
\hline
\end{tabular}

According to the results of the LSD Post Hoc related to the candidate teachers' Total Environmental Awareness varied by the most important reason in choosing where to live, those who prioritize Degradation of natural beauties as the most important reason have a more negative environmental awareness than those choosing by Concrete, Air / water pollution concern, Relinquishment also demands to leave and Other (Table 17). 
Table 17. ANOVA LSD Post Hoc Results by Choosing a Living Place

\begin{tabular}{llcccc}
\hline \multirow{2}{*}{ Dependent variable } & & $\begin{array}{c}\text { Mean difference } \\
\text { (I-J) }\end{array}$ & Std. error & Sig. \\
\hline \multirow{4}{*}{$\begin{array}{l}\text { Total } \\
\text { environmental }\end{array}$} & Degradation of & Concrete & -0.230 & 0.069 & 0.001 \\
awareness & Air / water pollution concern & -0.223 & 0.091 & 0.014 \\
& & Relinquishment also demands to leave & -0.235 & 0.119 & 0.049 \\
& & Other & -0.152 & 0.062 & 0.015 \\
& Concrete & Degradation of natural beauties & 0.230 & 0.069 & 0.001 \\
& Other & 0.078 & 0.039 & 0.049 \\
\hline
\end{tabular}

Below are the variables which lead to no variation in total and sub scales of environmental awareness:

- Do you like nature?

- Do you like animals?

- Do you like sea, land, ponds?

- Do you think to leave the place you live?

- Do you take care of your responsibilities to create a smooth future for your child?

- Have you ever been involved in any social service-social activity?

- Have you ever been involved in any environmentalist social work-social activity?

- Are you reluctant to take responsibility?

- Are you warned against faults?

- Why do you choose where you live?

\section{Discussion}

According to the results of the analysis, environmental awareness levels of teacher candidates have shown a meaningful difference according to the genders of teacher candidates at each sub-dimension ("To do", "Not to do" and "Current Threats") of the scale, and overall of the scale (Total environmental awareness) on the side of female teacher candidates. The findings obtained from the study show similarities with some results obtained from the studies made about this subject. Thus, Çelen et al. (2002) found out that female students are more sensitive to environment than male students at the study they made on university students. In the same way, Çabuk, and Karacaoğlu (2003) found a meaningful difference according to the genders of students on behalf of female students at their study where they analyzed environmental awareness of teacher candidates. Environmental attitude points of teacher candidates according to the gender also display a meaningful difference on the side of girls at the study of Erol and Gezer (2006). A meaningful difference has been determined between average points of gender, and environmental attitude on behalf of female students at their study Ek, Kılıç, Öğdüm, Düzgün and Şeker (2007) realized with university students. There exists a great number of studies resulted on the side of females according to emotional features about environment in addition to the researches mentioned above in the literature (Larijani, 2010; Aksoy and Karatekin, 2011; Gürbüz, Çakmak, \& Derman, 2013). On the other hand, Altın (2001) found out that there exists no difference at the attitudes of biology teacher candidates about environment and environmental problems according to gender. Yılmaz, Morgil, Aktuğ and Göbekli (2002) determined that female teacher candidates have higher attitudes than male teacher candidates, however, it is not at a meaningful level at their study when they analyzed environmental attitude points of primary school teacher candidates according to gender. In the same way, Karademir (2016) determined that there does not exist a meaningful difference at the self-sufficiency, and awareness levels of primary school teacher candidates about environment according to gender. Akçay and Pekel (2017) ascertained that environment awareness, and environmental sensitiveness of teacher candidates does not show a meaningful difference according to gender. Therefore, it has been understood from the similar studies made that while environmental awareness shows a meaningful difference according to gender in some studies, there may not exist a meaningful difference in some studies.

While there exists no meaningful difference according to the variable of marital status of teacher candidates about environmental awareness levels of them at sub-dimension of "not to do", and overall of the scale (Total environmental awareness), a meaningful difference was found on the side of married ones at the sub-dimensions of "to do" and "Current threats". The findings obtained from the study make us think that married teacher candidates 
are more sensitive to environmental threats than single ones. However, similar studies made with the same independent variable have not been met in the literature. For this reason, this finding obtained from the study is original.

It has been found out a meaningful difference at the environmental awareness levels of teacher candidates according to the love of flower, tree, and green, and being respectful to the rights of living beings other than humans at the sub-dimensions of "to do", and "current threats" and total environment awareness, except the sub-dimension of "not to do" on the side of the ones who say "yes". This result is a desirable and expected one. Thus, Talay et al. (2004) discovered that students generally have a reasonable level of environmental awareness at their study to determine environment knowledge, and awareness level of Ankara University students.

A meaningful difference has been found at the environmental awareness levels of teacher candidates according to knowledge of negative effects of damage to the nature, and animals, and the environmental awareness levels of teacher candidates according to adopting nature, and animals as a part of their lives on the side of saying yes at the sub-dimension of "to do" depending on each independent variable. This result is an expected situation, and it coincides with similar results of works at literature (Oğuz, Çakıcı, \& Kavas, 2011; Ek, Kılıç, Öğdüm, \& Şeker, 2007).

Meaningful differences have been found when the environmental awareness levels of teacher candidates have been analyzed according to the variable of age at total environment awareness, and the sub-dimension of "to do" on the side of 18-25, and 26-35 ages. This finding resembles with the literature. Thus, a meaningful difference has been determined at the average points between students' age groups, and environmental awareness scale, and the ones 21 years old and older have had higher average points than the ones 20 years old and younger at the study made by Ek, Kılıç, Düzgün and Şeker (2007). In the same way, a meaningful difference is seen according to age, and students' attitude towards environment at the study of Erol and Gezer (2006). The attitudes of students older than 21 years old are more positive than the attitudes of students' younger than 21 years old.

A meaningful difference exists between $1^{\text {st }}$ grade, and $2^{\text {nd }}, 3^{\text {rd }}$ grades, and pedagogical formation teacher candidates on the side of $1^{\text {st }}$ graders when the environmental awareness levels of teacher candidates have been analyzed according to the variable of classroom according to "current threats" sub-dimension of the scale. It has been seen that researchers have reached different results when similar works have been analyzed in the literature. Hence, Karademir (2016) did not determine a meaningful difference at the environmental awareness points of teacher candidates according to their classroom. However, Çabuk and Karacaoğlu (2003) found a meaningful difference at the environmental awareness points of teacher candidates according to the variable of classroom. Environmental awareness levels of $4^{\text {th }}$ grade teacher candidates are higher than lower grade teacher candidates.

The environmental awareness of teacher candidates according to the variable of the most important reason choosing where to live displays significant differences. According to this finding, the ones choosing "concrete, air/water pollution concern, relinquishment also demands to leave, and others" show meaningful differences than the ones choosing "degradation of natural beauties". In the same way, the ones choosing "concrete" display meaningful differences than the ones choosing "degradation of natural beauties". Similar researches made with a similar independent variable have not been met in the literature. However, Erol and Gezer (2006) did not find a meaningful difference at the attitudes of teacher candidates towards nature according to living small and big cities. Nonetheless, Ek, Kılı̧, Öğdüm, Düzgün and Şeker (2007) found a meaningful difference at the attitudes of university students towards nature according to living in a city and village on the side of living in city at their study where they analyzed the place where they live the longest and environmental awareness of university students.

\section{Conclusion}

According to results of this research the candidate teachers have a very high level of environmental awareness and their environmental awareness show no variation by gender in the three sub-scales and the total awareness. But candidate teachers' environmental awareness vary by their marital status, favoring of flowers, trees and greens, whether they are informed about the future negative effects of damage to nature and animals, accepting nature and animals as part of their life/family, their age, which class they study and choosing a living place. Therefore, it should be investigated by new researches why these significant differences are caused. Further this research was conducted on prospective teachers. So similar research can be carried out on teachers.

While classes and content to raise environmental awareness are not widespread in all departments and course contents in the education faculties, a high environmental awareness level, maintained by the modern mentalities of 
academic staff and students, has been found. However, to remove this from personal interest and initiative and render it systematic, candidate students who will address future students of varying age and branches should receive environmental courses coherent with the course contents they'll teach. In addition, the following recommendations were developed in the light of the results of the study:

Environmental issues should be taken into consideration as part of a systemic integrity. Each geographical region should be assessed in a systemic integrity along with their ecosystem, culture and natural assets, tourism and economy. Certainly, the economic and sociological needs of the region's population should also be on the foreground. Therefore, to serve the economic development of the region without interrupting its natural balance, it is intended to become a touristic region.

Flora and fauna must be preserved. Forests are home to many species. All flora housing endemic species, primarily forests and mountains, must be preserved. New industrial facilities, mining survey, destructive energy generation and transportation systems, which may threathen the natural life and disrupt the natural balance in the region should never be permitted, and in fact existing facilities should not be operated and unnecessary concrete formations should be prevented. Trees should not be cut down for any reason, especially mining surveys.

Pollution must be prevented. All forms of environmental pollution must be prevented. The air, water and earth, as the sources of life, should be preserved in "clean" condition for mankind, animals and plants. Any threat of pollution against such sources of life should be prevented before realization, or immediately remedied if realized. Any threat to the existence of forests should be eliminated Thermal/nuclear plants should never be considered an option, initiatives that may cause deforestation should not be permitted. Any initiative leading to the pollution or threatening the existence of water sources should be prevented. Mining survey licenses should not be granted in the vicinity of water sources, and industrial facilities should be prevented from discharging/contaminating wastes into such water sources. Industrial facilities must be strictly supervised to ensure they establish treatment plants to avoid environmental pollution.

It has been established that the pollution of soil and water leads to cancer formation in humans through food. Such metallic pollution in the water affect all produce in irrigated farms, thus inevitably causes significant harm to human health. Treatment plants should be established to prevent sewage waste from polluting rivers and creeks.

In recent years, greater amounts of fertilizers, water and chemical pesticides have been used in agricultural land to increase output. In particular, the hybrid seeds are renewed each year, thus pesticides are applied to the soil against harmful organisms which will be forced to develop resistance for the seed, increasing soil toxicity. The soil and water, polluted over a quarter of a century, become unable to renew itselfs in thousands of years. Nitrogenous fertilizers lead to an increase in nitrate pollution in underground water sources. Soil fatigue and pollution should be prevented. Penal sanctions should be implemented. Thousands of facilities continue to pollute the environment, it will not be possible to prevent pollution without implementation of measures. No penal sanctions are implemented to organizations polluting the environment, no factory is prosecuted or penalized.

Green energy industry should be prioritized. One of the fundamental requirements of development is energy generation. Current energy generation and consumption systems lead to the pollution of air, water and earth at local, regional and global level. The most important instrument in reducing contaminants is energy systems established to contain new and renewable energy that are environment-sensitive and sustainable. Coal and thermal plants lead to serious concern in the scientific world, primarily due to negative health and environmental effects and climate change. Coal-fired thermal plants built within settlement areas increase the health issues for the inhabitants. In the recent years of where renewable energy resources were ignored in a tendency towards nuclear and coal-fired thermal plants, energy industry is one of the leading sources of environmental issues.

The global oil crisis of 1973 led to increased interest in alternative and renewable energy resources. The fossil fuels, which fulfill a significant portion of the global energy requirements, have limited time of use, lead to destruction of the environment during energy generation, which combined with the energy requirements of the future generations, better demonstrates the significance of renewable energy resources. Widespread and large-scale use of such resources is subject to techonological developments and the establishment of national and international information networks to determine its potential. The first alternative energy resources to be considered are wind and solar energy.

\section{References}

Akçay, S., \& Pekel, F. O. (2017). Investigation of prospective teachers' environmental awareness and sensitivity in terms of different variables. Elementary Education Online, 16(3), 1174-1184. 
Aksoy, B., \& Karatekin, K. (2011). Affective tendencies of undergraduate students in different programmes toward the environment. Turkish Journal of Social Research, 15(3), 23-36.

Altın, M. (2001). Biyoloji öğretmen adaylarında çevre eğitimi. Unpublished master's thesis. Ankara: Gazi University.

Çabuk, B., \& Karacaoğlu, Ö. C. (2003). Üniversite öğrencilerinin çevre duyarlılıklarının incelenmesi. Ankara University Journal of Faculty of Educational Sciences, 36(1-2), 189-198.

Çelen, Ü., Yıldız, A., Atak, N., Tabak, R. H., \& Arısoy, M. (2002). Ankara Üniversitesi Sağlık Eğitim Fakültesi öğrencilerinin çevre duyarliliği ve ilişkili faktörler. 8. Ulusal Halk Sağlığı Kongresi, Diyarbakır. Kongre Kitabı.

Ek, H. N., Kılıç, N., Öğdüm, P., Düzgün, G., \& Şeker, S. (2007). First and senior class Adnan Menderes University student's attitudes, towards environmental problems. Kastamonu Education Journal, 17(1), 125-136.

Ergin, D. Y. (2017). Çevre bilinci ölçeğinin geliştirilmesi. ICSER-3rd International Conference on Social Sciences and Education Research. Rome / Italy 27-29 April 2017.

Erol G. H., \& Gezer, K. (2006). Prospective of elementary school teachers' attitudes toward environment and environmental problems. International Journal of Environmental and Science Education, 1(1), 65-77.

Gürbüz, H., Çakmak, M., \& Derman, M. (2013). Biyoloji öğretmen adaylarının sürdürülebilir çevreye yönelik tutumları. Turkish Journal of Scientific Reviews, 6(1), 144-149.

Karademir, E. (2016). In the structuring process of education faculty; determination of the teachers' environmental consciousness and self-efficacy. Journal of Education and Humanities: Theory and Practice, 7(13), 3-18.

Larijani, M. (2010). Assessment of environmental awareness among higher primary school teachers. Journal of Human Ecology, 31(2), 121-124. https://doi.org/10.1080/09709274.2010.11906302

Oğuz, D., Çakc1, I., \& Kavas, S. (2011). Environmental awareness of students in higher education. SDU Faculty of Forestry Journal, 12(1), 34-39.

Özdemir O. (2007). A new environmental education perspective: Education for sustainable development. Education and Science 2007, 32, 145.

Özdemir O. (2016). Ekolojik okuryazarlı ve çevre eğitimi. Ankara: Pegem Akademi. https://doi.org/10.14527/9786053185970

Şimşekli Y. (2004). Sensitivity of elemantary schools to the environmental education activities for increasing environmental knowledge. Journal of Uludag University of Faculty of Education, XVII(1), 83-92.

Talay, İ., Gündüz, S., \& Akpınar, N. (2004). On the status of environmental education and awareness of undergraduate students at Ankara University, Turkey. International journal of Environment and Pollution, 21(3), 293-308. https://doi.org/10.1504/IJEP.2004.004196

Yılmaz, A., Morgil, İ., Aktuğ, P., \& Göbekli, İ. (2002). Knowledge of the secondary school and university students on the environment, environmental concepts and problems and suggestions. Journal of Hacettepe University Faculty of Education, 22, 156-162. 